Oana Fotache Dubălaru

oanaanca.dubalaru@g.unibuc.ro

University of Bucharest

Faculty of Letters https://doi.org/10.18485/knjiz.2021.11.11.4

UDC: 821.135.1.09-95 Ловинеску М.

821.135.1-055.2

Original scientific article

\title{
Towards an Ethical Canon of Postwar Romanian Literature: Monica Lovinescu on Women Writers ${ }^{1}$
}

This paper looks into Romanian critic Monica Lovinescu's writings in order to identify the criteria she employs for the analysis of Romanian women writers after World War II. Covering mostly fiction and memorialistic literature, Monica Lovinescu played an important role in launching the careers of contemporary women writers, while also revisiting forgotten or marginal texts authored by members of older generations. Her value system brings together aesthetic and ethical frameworks that take into account the larger socio-political context which the writers relate to. Even though the critic's way of reading is not an explicitly feminist one, her analyses and hermeneutical technique still consider the writer's gender, especially as she thinks that Romanian women writers were often marginalized by male scholars who dominated the literary field during and after communism.

Keywords: Monica Lovinescu, literary criticism, women writers, ethics, literary value

\section{Portrait of the Critic as an Exile}

For many Romanians who were secretly listening to Radio Free Europe’s broadcasts during the 1970s and 1980s, Monica Lovinescu (1923-2008) was just a voice and a name, with no recognizable face. The name was familiar from the school textbooks that were in use after the political and cultural liberalization at the beginning of the '60s (the so-called Thaw), or from personal libraries - those in which forbidden books had survived, before their gradual and partial reintegration into the public circuit. The literary critic and historian Eugen (E.) Lovinescu (1881-1943), Monica's father, was one of the most prominent creators of the modernist literary canon during the interwar period and also the most active promoter of Romanian culture's synchronization with Western culture.

Monica Lovinescu's voice was familiar to Romanian audiences from her weekly radio broadcasts “Theses and Antitheses in Paris” (Teze și antiteze la Paris, since 1962) and "Romanian Cultural News" (Actualitatea culturală românească, since 1967). A bit hoarse, it was the voice of a heavy smoker, penetrating and firm yet pleasant, with a charming French accent. $^{2}$ Monica Lovinescu's public image was rather stereotypically masculine, from her habitual outfit (she used to wear blue jeans and shirts) to her legendary courageous attitude, 
tough and uncompromising, first and foremost towards herself. The almost mythical dimension of her image in the eyes of most Romanian writers and radio audiences who had not met her in person are alluded to in a humorous tone in a diary entry (dated 7 October 1985), where she recalled how the group of dissidents at the Dialog (Dialogue) magazine in Iași had pictured her. They imagined she must be "big and imposing” (mare și impunătoare) and were curious about her clothing decisions, "guessing about some formal tailleur” (bănuind cine știe ce tailleur sever). When told that she preferred blue jeans, "they burst out with joy and kept on talking only about it” (i-a apucat bucuria pe toți, de nu mai vorbeau decât de asta (Lovinescu 2010a: 166$)^{3}$

Yet despite this image, women occupied a special place in her writing and her life, starting with her mother whom she had to leave behind in 1947, the year she settled in France. Ecaterina Bălăcioiu Lovinescu was arrested and imprisoned at 71, and died in prison due to lack of medical care - a tragedy that would haunt her daughter all her life. Then there were numerous feminine presences in Lovinescu's diaries, memoirs, and radio pieces about books which she later gathered and published in the series Unde scurte (Short Waves). ${ }^{4}$ The readers encounter a variety of such feminine types in her writings: the activist/dissident, the artist, the intellectual, the journalist (trained as a theater director, she gave up this passion in favor of a journalistic career). ${ }^{5}$ Many of these women she actually met in Paris over the years, as exiles or visitors. Others she would meet only after 1989, during her visits to Romania.

The echoes of these personalities are followed on different levels: political, ethical, social, cultural. Monica Lovinescu designed for her own use a personal pantheon of courage, whose legendary figures were Nadezhda Mandelstam, Anna Akhmatova, and Lidia Ciukovskaia. If the presence of the first two writers could be easily anticipated, and Monica Lovinescu did not feel the need for additional explanations, about Lidia Ciukovskaia she wrote some poignant, moving pages that introduced to Romanian readers a less known figure, endowed with an exemplary moral consciousness. The Romanian critic pictures her in several scenes: when repeating Akhmatova's poems in order to learn them by heart and thus preserve them in a "critical edition of oral memory" (ediție critică a amintirii orale, Lovinescu 2010b: 484), which Monica Lovinescu would compare to the poems memorized by the inmates of Romania's political prisons; ${ }^{6}$ or when Ciukovskaia was the only one to protest against Solzhenitsyn's exclusion from the Soviet Writers' Union. This is typical for the way in which Monica Lovinescu usually envisions the mission of contemporary writers, whom she always validates from two perspectives, talent and conscience. To her, such models as Ciukovskaia's set a high standard for any gesture in the literary field, especially under a totalitarian regime, a 
standard that Romanian writers would be measured up against. This also explains why the impressions left by someone's literary work and communicated in a radio chronicle have to be confirmed by that writer's civic and ethical actions.

There are clearly important differences in tone (not in attitude, though) among the genres that Monica Lovinescu practices in her writing. Her diary which encompasses, in the published form, ${ }^{7}$ two decades reflects the same themes, doubts, reactions as the literary critical pieces she read into the microphone, but in a transparent manner. Her memoirs, La apa Vavilonului (By the Waters of Babylon) are written more freely, without constraints, letting the affective logic insert longer or shorter parentheses, thus conflicting with the temporal order to achieve coherence at the level of ethical significance. The chronicles carefully and elaborately approach their subjects (be it a book, a public gesture or action, a cultural event, etc.), in their inner structure and the socio-political implications alike, the latter pertaining to the immediate context or being explained by historical circumstances. Usually, her discourse would avoid feminine adjectives and first-person singular pronouns in criticism but would make use of them in her diaries or memoirs. A more personal, subjective tone would come up in her literary criticism only after 1990. In the Short Waves pieces, the first person plural, frequently employed, refers to a topos of the scholarly discourse of the interwar period, when she grew up and completed her studies; it could also signal an attempt to build up a sense of solidarity with the listeners, with whom she maintains the feeling of a permanent dialogue and a liberating complicity; but it can also be viewed as an expression of the consonance in attitude and eastethic vision (a term she coined to emphasize the solidarity of the aesthetic and ethical principles) of the couple she formed with Virgil Ierunca. ${ }^{8}$

Beyond the differences in stylistic register, one can notice a permanent transfer among these texts that belong to various genres. Phrases from chronicles can often be found in her diaries (the impact of which is exerted here before they are developed and polished in the spoken text). A lot of contextual information, meant to explain the selection of topics as well as a reaction towards one writer or another, are to be found in the diaries, where Lovinescu puts down details of visits and discussions with writers who had just arrived from Romania, plans she and Ierunca were making with members of the Parisian diaspora (protest meetings, various campaigns for the benefit of dissidents), or details of the often intricate negotiations she had to conduct with the management of Radio Free Europe based in Munich. For a general panorama of the time (Cold War and its effects at the cultural level) and of the milieu in which her critical action had taken effect for more than four decades, in Romania and in the Parisian exile, the memoirs are a valuable guide. ${ }^{9}$ The same themes can be identified in everything she 
wrote: first, the emphasis on the similarity between left-wing and right-wing totalitarianism. Lovinescu bitterly notices the resistance with which the first of them was acknowledged in Western political and intellectual circles, especially in France. The theoretical ground for her analysis in this respect could be found in books by the philosophers Jeanne Hersch and Hannah Arendt, both barely known to Romanian readers at that time, whom Lovinescu often mentions in her critical pieces and diary entries. These references may be viewed as an attempt to revisit and underline important feminine contributions to European knowledge and culture.

\section{Reading Contemporary Women Writers against the Grain}

Although the critical essays on Romanian women writers, living in Romania or in exile, are not very numerous (for several reasons), they are important through what they reveal concerning the critic's view on the role of literature in general, and on works by women writers in particular, in a totalitarian society. Monica Lovinescu was not engaged directly in feminist theory and criticism; actually, she strongly disliked outstanding feminist scholars such as Simone de Beauvoir and Julia Kristeva because of their commitment to leftist ideology. Another reason might be the reactive quality of her criticism, always ready to get involved in urgent issues with political relevance. And last but not least, women writers of the postwar period until the fall of communism were more interesting as poets than novelists.

The choice of names and titles about which Lovinescu writes is made according to complex criteria: the illustration of a theoretical or historical issue, the referencing of a literary novelty whose lasting impact is foreshadowed, the sanctioning of a compromise, etc. As for women writers’ literature, Monica Lovinescu remarks, in an extensive analysis from 1972 (which she first published in 1978, in an exile press from Madrid), that it was systematically ignored because of the writers' marginal social position, among other reasons. Women writers often remained outside the literary power game, as they were rarely in charge of a publishing house, or a literary journal, or a writers' association, etc. ${ }^{10}$ Some of Lovinescu's chronicles written after 1989 will mark the reconsidering of forgotten or unpublished writers active during the communist period, such as Jeni Acterian or Alice Voinescu, and the recognition and assessment of some recently published memorialists (Annie Bentoiu, Aniţa Nandriș-Cudla, and others). Other pieces are dedicated to writers in exile who were less familiar to Romanian readers at home (Ioana Cantacuzino/Oana Orlea, Adriana Georgescu-Cosmovici). Still others draw attention to Romanian authors who received less critical interest than their male colleagues of the same generation (Gabriela Adameșteanu, Adriana Bittel). All these instances 
prove Lovinescu's trained critical taste, the accuracy and soundness of her judgments, which would be later confirmed by the writers' reception in the Romanian literary field. At the level of axiological criteria, her interest in qualities such as complexity and authenticity (both of writers and their works) is apparent.

In what follows I will analyze some of Lovinescu's critical essays on women writers, in parallel with her remarks from the diaries and memoirs, so as to identify the coordinates that sustain her critical value system. At the same time, I will look into the role of gender differences in ensuring a canonical status for a writer, in the larger perspective of a literary historiography that deals with a period strongly affected by the communist ideology. It is precisely this political context that makes it impossible, in Monica Lovinescu's view, to maintain a purely aesthetic system of validation, as it had prevailed in Romanian literary field before the Second World War (largely due to her father's critical action). Therefore, she called for the need to supplement aesthetic criteria with ethical requirements that refer to a writer's conduct when faced with political/ideological constraints. The issue of an ethical version of the literary canon (a canon defined solely from an aesthetic perspective by Romanian critics of the autonomist tradition) would be later approached by the theorist Sorin Alexandrescu, who attempted to find its sources in a less prominent literary trend of the interwar period. ${ }^{11}$ For Alexandrescu, influenced by the deconstructive paradigm, the obsession with the aesthetic canon in Romanian criticism and historiography was damaging because of its hierarchical and conservative assumptions.

Among the writers living in Romania, those that drew Monica Lovinescu's constant interest were Gabriela Adameșteanu, Ana Blandiana, and Adriana Bittel, all three of them members of a generation that had reached maturity at the time of the political thaw (after 1965, the year Nicolae Ceaușescu came to power). Ana Blandiana was the first to make her début in the literary world as a poet, at an auspicious moment for the revival of a lyrical discourse in the modernist vein, centered on the values of subjectivity and symbolism. The prose writers Gabriela Adameșteanu and Adriana Bittel started their careers later, in 1975 and 1980, respectively. This circumstance brought them closer to the '80s generation in terms of literary orientation, having been influenced by textualism and postmodernism. Monica Lovinescu wrote enthusiastically about Gabriela Adameșteanu in 1984, a few months after the publication of the novel which would bring her critical acclaim, Dimineață pierdută (Wasted Morning). The chronicle starts by registering the critic's surprise when reading Adameșteanu for the first time, immediately followed by the affirmation of a critical verdict which text-based arguments will later demonstrate. This verdict will be fully confirmed after 1989, when Adameșteanu 
becomes one of the most translated and appreciated Romanian writers. Lovinescu discovers a writer who is to be placed among "not only the greatest contemporary novelists, but also among the best of our entire literature” (nu numai printre cei mai mari romancieri contemporani, dar și printre cei mai buni din întreaga noastră literature; Lovinescu 2014: 371-372). In a diary entry that records the meeting with the writer in Paris, on 13 November 1987, the praise goes even further: Adameșteanu's novel is considered the best in Romanian postwar literature, alongside Marin Preda’s Moromeții (The Moromete Family, Preda was the absolute celebrity of the time). The writer as a person made an excellent impression on the IeruncaLovinescu couple: “We both liked her a lot. No surprise in that (after reading the book it's hard to feel different), but still a reason for joy” (Ne place la amândoi nespus. Nu e o surpriză [după carte era greu să fie altfel], e totuși o bucurie; Lovinescu 2010a: 227).

Coming back to the novel, the criteria for its appreciation are twofold: on the one hand, it is considered a "truly modern novel" (roman cu adevărat modern) by its composition and style; on the other hand,

despite the fact that it is in no way a political novel, the verisimilitude of all the details, as well as the unmatchable freedom of the tone make it one of the most truthful novels we had the chance to read (în ciuda faptului că nu e în nici un fel vorba de un roman politic, veracitatea tuturor detaliilor, cât și libertatea inimitabilă a tonului fac din el unul din romanele cele mai adevărate din câte ne-a fost dat să citim) (Lovinescu 2014: 373).

Here, "truthful" means authenticity of the characters and of the writer's perception, honesty, and lack of compromise with the ruling ideology. The unforgettable protagonist, Vica Delcă, embodies these qualities, as she is "at odds with grammar, but not with the truth, notwithstanding her primitivism” (certată cu gramatica dar, în ciuda primitivităţii sale, nu și cu adevărul; Lovinescu 2014: 376). Truly impressive is the critic's ability to empathize with the fictional world and to establish a sense of solidarity with her Romanian audience. The novel is interpreted from a mobile perspective, in which "we, the readers of today" (noi, cititorii de acum; Lovinescu 2014: 373), able to see what the characters ignore, are somehow part of the narrative fabric. ${ }^{12}$ The only critic from Romania to whom she refers in this chronicle (actually, in many others) is Nicolae Manolescu, the most important representative and defender of the aesthetic/autonomist direction in the Romanian literary criticism of the '60s-'80s period, and with whom she generally agrees. Manolescu had read this narrative as a "women's novel” (un 
roman al femeilor) because of the gossipy environment where feminine conversations prevail. Monica Lovinescu subtly corrects him and draws attention to other distinctive features:

Wasted Morning is probably a novel of decrepitude in the first place, the characters' decrepitude, the time’s, its disintegration, its mouldiness (Dimineață pierdută e, poate, în primul rând un roman al bătrâneții, bătrânețea personajelor, bătrânețea timpului, destrămarea, mucegăiala lui) (Lovinescu 2014: 373).

Even though the critic's way of reading is not an explicitly feminist one, here as in other essays, her value judgments and hermeneutics still take into account the writers' gender, especially as she thinks that women writers in Romania are more often than not marginalized if not excluded by (male) literary critics and historians. Other important stake is the writers' inclination towards a strong ethical attitude. For instance, Lovinescu reacted to the general enthusiasm with which Romanian critics had greeted a historical and political novel such as Marin Preda's Delirium (Delirul). She based her argument on a moral ground, by quoting from Nadezhda Mandelstam's Memoirs and also referring to Solzhenitsyn as beacons to be followed in such matters. ${ }^{13}$

About the other prose writer who became known in the '80s, Adriana Bittel, Monica Lovinescu wrote two chronicles, six years apart. The first was titled "Can one live in this historical time?” (Se poate trăi în istorie?), and the writer’s work is set against that of Ștefan Agopian, an important male novelist of the '80s generation, generally associated with the Balkan and aestheticist style in Romanian fiction. The structure of the argument is similar to the case of Gabriela Adameșteanu’s novel: the chronicle begins in a (partial) agreement with the remarks of an important Romanian critic, who was also the editor of a collective volume of short stories, Landing 83 (Desant 83), viewed as the manifesto of a new literary generation, affiliated to postmodernism - the 1980s generation. This critic did not write about Adriana Bittel, who was not included in the collective volume; yet Lovinescu transfers his comments to her work and places her "at the antipode of Ștefan Agopian's textual nonrealism” (la antipodul irealismului textual al lui Ștefan Agopian; Lovinescu 2014: 379) by her negative reaction to the times. Commenting on Bittel's radicalism, Monica Lovinescu anticipates the novelist she would become, a promise that was fulfilled by the novel Fototeca (The Photo Library). This novel will be published in 1989, and Lovinescu discusses it from the angle of the French Nouveau Roman, the influence of which was perceptible in Romanian literature starting from the '70s. Only that, with Adriana Bittel, the theme of vision (Fr. regard) acquires 
ethical and political connotations of the "memory-vision" type (privire-memorie). The feminine protagonist of the novel works at the photo library of a magazine, where she is in charge of retouching the photos. Thus, she becomes part of the general process of "constant fake" (falsul permanent), with the exception that this character's struggle is to reinforce the truth, so the critic writes, and then she leads the readers towards a general picture of totalitarian society, where the fake rules "not only the economic field, the political one, the media" [nu doar economicul, politicul, mass-media], but also lives of ordinary people (Lovinescu 2014: 382). Lovinescu expresses her strong belief in a critical judgment that is based on the reception of a work rather than on textual structures, as it was customary at the time. From this vantage point, she is convinced that the novel can stand a post-totalitarian reading very well. The Photo Library's second edition came out in 2015 and it enjoyed critical acclaim. The diary entries from the spring of 1990, when Monica Lovinescu visited Romania for the first time in 43 years, confirm the positive impression left by Bittel's books. During a period when Lovinescu declared her disappointment with the new pact signed by Romanian writers with the state authority, Bittel kept her strong moral opinions and valid intuitions. ${ }^{14}$

Adameșteanu and Bittel are not the only writers appreciated by Monica Lovinescu for the balance they were able to maintain between writing and moral/civic attitude: Ana Blandiana, whom I have already mentioned, a famous dissident and after 1989, one of the intellectuals actively involved in politics and the public sphere; the poet Ileana Mălăncioiu; ${ }^{15}$ the novelist Dana Dumitriu, whose historical/political novel Prinţul Ghica (Prince Ghica) Lovinescu reviewed on 26 November 1986. To them one could add several personalities of the Romanian cultural world, such as the legendary piano player Cella Delavrancea ${ }^{16}$ or the editor Georgeta Dimisianu, praised for their courageous attitude during the communist period.

About Ana Blandiana, one of the most celebrated poets of the '60s generation, Monica Lovinescu wrote less frequently and mostly on her prose pieces, as she had an agreement with her husband, Virgil Ierunca, to cover different genres: for the Radio Free Europe broadcasts he wrote on poetry and philosophy books, while she dealt with fiction and criticism. One of these chronicles on Blandiana's books comments upon the writer’s travel diary (23 March 1979). The travelogue was titled Cea mai frumoasă dintre lumile posibile (The Most Beautiful of All Possible Worlds ${ }^{17}$ and narrated a trip in Romania. The critic starts by expressing her mistrust in the text's genre: "I am no big supporter of travelogues or travel guides published in Romania” (nu sunt mare amatoare de jurnale și cărți de călătorie ce apar în România; Lovinescu 2014: 358). (Here one can find a feminine form of the adjective, quite rare in Monica Lovinescu's writings.) Another mistrust refers to the readers' anticipated reactions, as the 
majority of them were totally denied the experience of travelling abroad, so presumably they were less likely to indulge in such a reading. Though she is keen on noticing the authenticity of the writer's perception, as well as her erudition, and the tone of the chronicle is generally positive yet unenthusiastic, the critic takes some distance regarding a significance attributed to a central motif in the book. The author employs an oneiric image (quite conventional, actually) of a stucco Atlas carrying a rotten globe, which the critic insists on reading in a political key:

Even if we assign to this image a different meaning than the one suggested by Ana Blandiana, if this globe seems to us to be rotten because of what it had to support in terms of injustices and tyrannies, if we picture it surrounded on its whole diameter by some kind of a fire circle of ideologies, tied up in its strap made of iron and suffering, the Atlas in the writer's mind has also other reasons to torment itself (Chiar dacă dăm acestei imagini un alt sens decât cel sugerat de Ana Blandiana, dacă globul acesta ni se pare nouă măcinat mai ales de tot ce are de suportat ca injustiții și tiranii, dacă-l vedem înconjurat pe întregul său diametru de un fel de cerc de foc al ideologiilor, prins în chinga lui de fier și suferințe, Atlasul din închipuirea autoarei mai are și alte motive de a se chinui) (Lovinescu 2014: 359).

\section{Reading on the Margins of Literature}

Such caution in interpretation, generated by the permanent watch on demises of integrity - as Monica Lovinescu practices a close hermeneutical reading not only of books, but of authors too - will disappear from the chronicles about women writers that publish their books after 1989 (such as Annie Bentoiu, the wife of the modernist composer Pascal Bentoiu, and her memoirs titled Timpul ce ni s-a dat (The Time that is Given to Us), 2000; or Aniţa Nandriș-Cudla, a peasant from Bukovina deported to Siberia who had survived there for twenty years).

Monica Lovinescu wrote passionately on the overwhelming memoirs of Nandriș-Cudla (20 de ani în Siberia [20 Years in Siberia], 1991), and on Elisabeta Rizea's fate ${ }^{18}$ - another victim of communist persecution. At the same time, Lovinescu underlines the cowardice of professional writers, contrasted with the revelations brought by these women's courage and dignity. The critic is utterly moved by the normality and genuineness of such testimonies, by their profound capacity to understand and accept the trials of fate with a dignity that can do without intellectual motivations. With no literary intentions and no stereotypes either, 
displaying a fresh quality seemingly "before the tower of Babel” (înainte de Turnul Babel;Lovinescu 2014: 411), Nandriș-Cudla’s book should not be judged according to some $a$ priori literary features, writes the critic (on 14 March 1992), but instead appraised by its affective and moral impact on the readers, by the life lesson it offers to them. It was precisely in such futile debates on the literary status of prison memoirs that Romanian literary critics and historians engaged after 1990. However, this specialized conversation did not affect in any way the extraordinary impact such books have had.

Quite the same strong mark was left by the memoirs of Annie Bentoiu (1927-2015), writer and translator from/into French. Bentoiu was born in a mixed family, her mother was French, so she was perfectly bilingual. Her memoirs, written and published late in her life, in 2000, describe a tragic period of Romanian history, a time when she suffered great hardship which she nevertheless narrates “with moderation, grace, and decency” (cu măsură, cu grație, cu decență; Lovinescu 2014: 438). From an avalanche of thematically similar testimonies, Monica Lovinescu selects this one which she welcomes "with gratitude [as] a book with no tears, no exclamation points, no exhaustive or theoretical pretense” (să întâmpin cu recunoștință această carte fără lacrimi, fără puncte de exclamație, fără pretenții exhaustive sau teoretizante; Lovinescu 2014: 439). This gratitude originates in the avoidance of the pathetic impulse which lends credibility to a book written "as I suspected it would be possible only later” (cum îmi închipuiam că se va face mult mai târziu; Lovinescu 2014: 439). This book succeeds in restoring the truth of a period which many people rush to deem softer than the fascist one, writes Monica Lovinescu.

Perhaps the most personal commentary, in which the borders between chronicle, diary, and memoir are effaced in Monica Lovinescu's writing, is the one about Adriana GeorgescuCosmovici’s book, La început a fost sfârșitul (In the Beginning Was the End, August 1993). This was also a gesture of restoration since the book had been first published in French in 1951. At that time its purpose was to provide a relevant and credible document on the emergence of the communist regime in Romania. Adriana Georgescu-Cosmovici was an early member of the anti-communist movement in her youth, soon after the end of the war, and one of the first victims. Exiled to France in 1948, in an environment far from friendly to the political refugees from Eastern Europe, Georgescu was encouraged by her close friend Monica Lovinescu to write this testimonial book in which to make her story known. The book was translated by Lovinescu chapter by chapter, as it was written, and will be retranslated into Romanian and published only in 1992. In her essay, the critic brings it into the present of the anti-communist protests in the University Square in Bucharest and uses this opportunity to briefly recall the 
political history of the postwar era for the benefit of the contemporary readers of 1993. In the deplorable context of the 1950s (but also in the '90s, defined in Romania by the confused transition towards democracy), M. Lovinescu reminds of Simone Weil’s words: “true courage [...] is to fight with no hope” (adevăratul curaj [...] este să lupți fără nădejde; Lovinescu 2014: 415). She emphasizes the quality of such a testimony, as well as its actual value. In the critic's view, this is yet another argument for the strong link between who a writer is and what he/she writes.

\section{Conclusion}

How are we supposed to read these texts (chronicles, diary entries, memoirs...) in our own time? ${ }^{19}$ Many of them have been written with a sense of urgency, of the necessary gesture that was meant to keep an ethical compass during troubled and menacing times. The so-called direction criticism was more difficult to practice inside the borders of Romania (a mission assumed first and foremost by Nicolae Manolescu); it became a way of life for Monica Lovinescu in her Parisian exile. Following the spirit of a family tradition she not only inherited but also embodied (what the French sociologist Pierre Bourdieu termed as habitus), ${ }^{20}$ Monica Lovinescu placed integrity, ethics, determination, and civility among the first in the catalogue of intellectual virtues. These seemed to her more important and rare than someone's "professional” value: "Talent, in our people, is abundant. Character is infinitely more rare” (Talentul, la noi, prisosește. Caracterul e infinit mai rar; Lovinescu 2010a: 250). To her, one of the most damaging effects that communism had was precisely the moral debasement of people and the vulgarization of society. Under these circumstances, Romanian intellectuals have adopted a strategy called "resistance through culture”, which Monica Lovinescu deplores ${ }^{21}$ as too aesthetically oriented and weak, when compared to other Eastern European nations.

More precious are those literary acts and consciences that could compensate for such demise or excuses. They were not just feminine; but some of the brightest examples that Lovinescu discovers are coming from women writers. In Monica Lovinescu's cultural commentaries as well as in her political strategies one can detect the configuration of an alternative canon ${ }^{22}$ that clearly deserves to be further elaborated and discussed in Romanian literary circles. Generally, the emphasis on the ethical value of writing was placed intermittently inside the Romanian cultural field. For Monica Lovinescu, the value of a literary work and the human quality of its author are inseparable. Her famous parable of the two types 
of ink, one used for writing a newspaper article, the other for a "literary work," which contaminate each other, strongly affirms her stance:

It's just that the pen remains the same: with only one ink (one conscience) you cannot get two different colors of writing. And I have witnessed an unexpected phenomenon, as simple as the moral of a fable: literary works, even when guarded, privileged in this impossible halving, have withered aesthetically, because they were the outcome of ethical defiance (Numai că peniţa rămînea aceeaşi: cu o singură cerneală (de fapt, o singură conştiinţă) nu poţi obţine două culori diferite ale scrisului. Şi am asistat la un fenomen neaşteptat, simplu ca morala unei fabule: operele - chiar aşa păzite, privilegiate în această imposibilă dedublare - s-au ofilit din punct de vedere estetic, pentru că erau rezultatul unei sfidări a eticii) (Lovinescu 1994: 340).

A warning that is still valid today.

\footnotetext{
${ }^{1}$ A version of this paper was presented at the lecture series "Women in Balkan literature and culture: subversive readings and identity challenges" organized by the universities of Ghent and Manchester. I would like to thank the organisers, Dr. Miglena Dikova-Milanova and Dr. Adelina Angusheva-Tihanov for their invitation.

${ }^{2}$ In April 1990, a young critic named Ion Bogdan Lefter confessed to Monica Lovinescu that it seemed to him her physical appearance did not match her voice at all. He was surprised to see that she was actually "a short and nice lady” (o doamnă mică și bună; Lovinescu 2003 : 88). M. Lovinescu answered jokingly that she had always been compared with Yekaterina Furtseva, "the horrific" minister of culture of the USSR during the 1960-1974 period. (All translations are mine unless otherwise stated.)

${ }^{3}$ For a discussion on the mythology of blue jeans in Romanian literary and popular culture during the 1980s see Magdalena Răduță, "Blue Jeans, Red Country: Young Writers in Romania in the 1980s”, Journal of World Literature 3, No. 1 (2018): 72-93.

${ }^{4}$ A first and partial edition is printed by an exile press in 1978, then a complete edition is published in Romania, after 1990.

${ }^{5}$ She comments on the writers who were Party allies in articles on ideological topics. For instance, she disapproved of Nina Cassian (a prominent figure at the time and later an exile in the USA) for "her absurd loyalty to an ideal communism, present only in her own mind" (fidelitățile ei absurde pentru un comunism ideal, sălăşluind doar în mintea ei; Lovinescu 2010a: 246).

${ }^{6}$ A terrible reality to which Lovinescu would always return in her writing. In a diary entry dated 19 September 1995, she put down information on political prisoners in the Romanian Gulag: "There have been 200 places of detention. The verdicts cumulated 25 million years. There were registered 3 million entries to prison (some people being arrested multiple times). Approximately 300,000 deaths in prison. Again approximately, 10,000 women.” (Au existat 200 de locuri de detenţie. Pedepsele s-au ridicat la 25 de milioane de ani de detenție. Au fost înregistrate 3 milioane de intrări în închisoare [unii fiind arestaţi de mai multe ori]. Aproximativ 300.000 de morţi în detenţie. Tot aproximativ, 10.000 de femei;Lovinescu 2010a : 402).

${ }^{7}$ Sections of the unpublished diaries will be rewritten and included in her memoirs.

${ }^{8}$ Virgil Ierunca (1920-2006) married Monica Lovinescu in Paris, in 1952. They knew each other from Bucharest and both left Romania in 1947. Ierunca was a poet, a literary critic, a journalist, and a very active personality of the Romanian diaspora in Paris. He was the editor of several cultural magazines, as well as the author of books of poetry, literary criticism, and essays on political, philosophical, and
} 
cultural topics. He and Monica Lovinescu had a very close partnership in every personal and professional aspect of their lives, imbued with mutual admiration and the sense of a shared vocation.

${ }^{9}$ They end up in 1980, when she resumes her diary.

${ }^{10}$ See Lovinescu 2014: 135.

11 "Pentru un mai grabnic sfârșit al canonului estetic" (For a quicker end to the aesthetic canon), 1997, included in Sorin Alexandrescu, Privind înapoi, modernitatea (Looking Backward, Modernity), 1999.

${ }^{12}$ See also: "But this is obviously our conclusion, the readers', not the character's" (Dar aceasta, evident, este concluzia noastră, a cititorilor, nu și a personajului; Lovinescu 2014: 375).

${ }^{13}$ Nadezhda Mandelstam is mentioned again in contrast with Romanian writers' compromises, which they would justify by the necessity to get their works published. This attitude led to the thesis of "resistance through culture" that would define the peculiarity of the Romanian dissidence movement (weak as it was) in the Central and East European context: "should I ask myself why this scene, and also Anna Akhmatova's Requiem, and Nadezhda Mandelstam's memoirs come to my mind every time I hear that one writer or another in Romania explains his ethical demise, concessions, or even his homage to the Court by the necessity to see his work published - the only thing that matters?” (să mă mai întreb de ce scena aceasta, ca şi Requiemul Annei Ahmatova, ca şi paginile de memorii ale Nadejdei Mandelștam îmi revin în minte ori de câte ori aud un scriitor sau altul din România explicându-şi demisiile, concesiile sau chiar laudele aduse la Curte prin necesitatea de a-şi vedea opera - singura ce contează - publicată?; Lovinescu 1994: 194).

${ }^{14}$ See Lovinescu 2003: 76, 85.

${ }^{15}$ Lovinescu praises her for the stance she took at the 1981 Writers' Conference: "she was truly bold" (a fost cu adevărat îndrăzneață; Lovinescu 2010a: 23).

${ }^{16}$ Cella Delavrancea (1887-1991), daughter of writer Barbu Ștefănescu Delavrancea, protested against the demolition of monuments and churches by writing a memoir addressed to Nicolae Ceaușescu himself.

${ }^{17}$ It may well be that the patriotic allusion in the title, indicating a possible compromise meant to secure the publication of the book, contributed to the critic's reserve.

${ }^{18}$ Although she had ceased writing for Radio Free Europe, in August 1992 Monica Lovinescu was so impressed by the courage and resilience shown by Elisabeta Rizea, a peasant woman who had been detained as a political prisoner for 12 years, that she wrote an article and published it in the magazine 22, whose chief editor was Gabriela Adameșteanu (see Lovinescu 2003: 266-267).

${ }^{19}$ The published work has to be corroborated with the impressive archive of the Lovinescu-Ierunca couple, which is currently in Bucharest. Details about this archive can be found here: http://culturalopposition.eu/registry/?uri=http://courage.btk.mta.hu/courage/individual/n35700\&type=collections.

${ }^{20}$ See Bourdieu 2013.

${ }^{21}$ Here is one example out of many: "when we saw the Czech and Polish proposals for the issue of L'Autre Europe dedicated to culture in the East, we sighed. We barely have anything. Our essayists, even in exile, are doing... literature" (văzând sumarul promis de cehi sau polonezi pentru numărul din L'Autre Europe consacrat culturii în Est, suspinăm. Noi nu avem aproape nimic. Eseiștii noștri, chiar exilați, fac... literatură, 4 May 1987).

${ }^{22}$ Camelia Crăciun remarked that this had happened "by reconsidering forgotten, forbidden, or marginalized texts, intellectuals, groups, and journals" (Crăciun 2009: 288-289). 


\section{References}

Adameșteanu, Gabriela. Dimineață pierdută. București: Cartea Românească, 1983 / Wasted Morning. Translated by Patrick Camiller. Evanston: Northwestern University Press, 2011 / Une matinée perdue. Traduit par Alain Paruit. Paris: Gallimard, 2015.

Alexandrescu, Sorin. Privind înapoi, modernitatea [Looking Backward, Modernity]. București: Univers, 1999.

Bentoiu, Annie. Timpul ce ni s-a dat [The Time that is Given to Us]. București: Vitruviu, 2000.

Bittel, Adriana. Fototeca: temă cu variațiuni [The Photo Library: Theme and Variations]. București: Cartea Românească, 1989.

Blandiana, Ana. Cea mai frumoasă dintre lumile posibile [The Most Beautiful of All Possible Worlds]. București: Cartea Românească, 1978.

Bourdieu, Pierre. Outline of a Theory of Practice [1977]. Translated by Richard Nice. Cambridge: Cambridge University Press, 2013.

Crăciun, Camelia. "Monica Lovinescu at Radio Free Europe”. In The Exile and Return of Writers from East-Central Europe: A Compendium, editors John Neubauer and Borbála Zsuzsanna, 276-303. Berlin: Walter de Gruyter, 2009.

Georgescu-Cosmovici, Adriana. Au commencement était la fin: la dictature rouge à Bucarest. Paris: Hachette, 1951 / La început a fost sfârșitul. București: Humanitas, 1992 /In the Beginning Was the End. Translated by Dan Golopenția. Boston: ASPERA, 2003.

Lovinescu, Monica. Jurnal 1990-1993 [Diary 1990-1993]. București: Humanitas, 2003.

Lovinescu, Monica. Jurnal 1994-1995 [Diary 1994-1995]. București: Humanitas, 2004. 
Lovinescu, Monica. Jurnal esențial [Essential Diary]. Edited by Cristina Cioabă. Preface by Ioana Pârvulescu. București: Humanitas, 2010a.

Lovinescu, Monica. La apa Vavilonului [By the Waters of Babylon]. $2^{\text {nd }}$ ed. București: Humanitas, 2010b.

Lovinescu, Monica. O istorie a literaturii române pe unde scurte. 1960-2000 [A History of Romanian Literature on the Short Waves. 1960-2000]. Edited and preface by Cristina Cioabă. București: Humanitas, 2014.

Lovinescu, Monica. Posteritatea contemporană. Unde scurte III [Contemporary Posterity. Short Waves III]. București: Humanitas, 1994.

Nandriș-Cudla, Anița. 20 de ani în Siberia: destin bucovinean. București: Humanitas, 1991 / 20 Years in Siberia. Translated by Mabel Nandris. București: Editura Fundației Culturale Române, 1998 / 20 ans en Sibérie : souvenirs d'une vie. Paris: L’Harmattan, 2011.

Răduță, Magdalena. "Blue Jeans, Red Country: Young Writers in Romania in the 1980s”. Journal of World Literature. 3, No. 1 (2018): 72-93. 
Оана Фотаке Дубалару

oanaanca.dubalaru@g.unibuc.ro

Универзитет у Букурешту

Филолошки факултет https://doi.org/10.18485/knjiz.2021.11.11.4

УДК: 821.135.1.09-95 Ловинеску М.

821.135.1-055.2

Оригинални научни чланак

\section{Ка етичком канону послератне румунске књижевности - Моника Ловинеску о књижевницама}

Овај текст се бави радом румунске критичарке Монике Ловинеску у намери да утврди критеријуме које користи при анализи дела румунских књижевница након Другог светског рата. Рад Монике Ловинеску је обухватао махом фикцију и мемоаре. Играла је важну улогу на почетку каријера модерних књижевница а бавила се и заборављеним или маргинализованим текстовима старијих генерација. Њен систем вредности спаја естетичке и етичке оквире који у обзир узимају шири друштвенополитички контекст са којим се писци поистовећују. Иако рад ове критичарке није експлицитно феминистички, њене анализе и херменеутички приступ ипак у обзир узимају пол писца, нарочито зато што она сматра да су румунске књижевнице често маргинализовали писци мушког пола који су доминирали књижевним пољем током и након комунизма.

Кључне речи: Моника Ловинеску, књижевна критика, књижевнице, етика, књижевна вредност 